\title{
Toward a Political Economy of British Labor Law
}

\author{
Charles K. Rowley†
}

Throughout the past quarter-century, British labor markets have been characterized by an unusual degree of conflict, as measured by the number of agreements between employers and unions abrogated by unofficial union decisions, by days lost in strikes during the currency of existing agreements, by the prevalence of intimidatory and secondary picketing, by the evident political objectives of much strike behavior within public-sector industries, and by the strength of union opposition to trade-union reforms that are treated as commonplace elsewhere in Western Europe and in North America. ${ }^{1}$ A significant concomitant of such turbulence has been a relatively low rate of investment in British industry and a correspondingly low rate of productivity growth, whether measured in terms of output per man-hour or of total-factor productivity. ${ }^{2}$

In this paper I will argue that labor-market turbulence on the scale witnessed in Britain over the past twenty-five years is primarily the consequence of a system of legal immunities for trade unions, trade-union officials, and individual trade-union members unprecedented in the Western world. ${ }^{3}$ The legal immunities availa-

$\dagger$ Professor of Economics and Editorial and Program Director, Center for Study of Public Choice, George Mason University. This paper benefited significantly from symposium discussion and most especially from the constructive criticism of Robert Topel and Richard Epstein. I am also indebted to the assistance provided by James M. Buchanan, Charles Hanson, Gordon Tullock, Viktor Vanberg, and Jack Wiseman and to the participants in the Workshop Discussion of The Center for Study of Public Choice at George Mason University.

1 An authoritative account of this history is provided by SECRETARY OF STATE roR EMploymznt, Trade Union Immuntites, CMd. No. 8128 (1981) [hereinafter cited as Trade UNION IMMUNITIES].

'Henderson, Britain's decline; its causes and consequences, Economst, June 2, 1979, at $29,29$.

- See Trade Union ImMUnTTies, supra note 1, at 11:

In those countries in which strikes and other forms of industrial action are legally recognised the law is generally couched in the form of a positive right to strike subject to various restraining conditions and qualifications . . . . In Great Britain, for historical reasons, the law has taken a quite different form. The law governing strikes and other industrial action is based on a series of legal immunities which protect those who organise and take part in trade disputes from criminal and civil liability. Without these immunities most industrial action would be illegal. 
ble to trade unions and to individual trade unionists have exposed other citizens in some cases to severe coercion and have effectively destroyed their property rights without any possibility of legal redress. The sweeping discretionary powers acquired by union leaders as a result of such legal immunities, together with the positive right to the closed shop, ${ }^{4}$ have significantly restricted the opportunities of union members to voice their own concerns effectively or to "vote with their feet" by departing the unionized sector. Furthermore, these immunities have led to an absence of binding collective-bargaining agreements; this situation has encouraged contract breaches by many unions and has significantly increased the wealth-destructive uncertainty faced by employers. Perhaps most important of all, the fact that legal immunities are available only to a minority of the British people has infringed the consistency of the rule of law and has allowed unions to coerce British governments in ways that have harmed society as a whole.

Part I of this paper will offer an overview of British labor law as it has developed during the past one hundred years. This body of law has not consisted of a system of positive union and employee rights within a coherent administrative framework, but rather of a series of immunities from criminal, tort, and contractual liabilities. In Part II, I will show how British trade-union leaders, as a result of predictably low levels of monitoring by the rankand-file, have accumulated an excessive degree of coercive power that can affect the entire British economy. Part III examines the actual effects of that power. Finally, in Part IV, I will discuss the Thatcher Governments' attempts to reform British labor law in an effort to minimize the wealth-destroying behavior of the trade unions.

\section{British Trade-Union Legislation: The Immunities APPROACH}

Prior to legislative developments since 1979, British trade un-

4he Trade Union and Labour Relations Act, 1974, ch. 52, sched. 1, § 6(5), declared that closed-shop agreements were fair unless an employee genuinely objected to unionization on reasonable grounds. The Trade Union and Labour Relations (Amendment) Act, 1976 , ch. 7, § 1(e), narrowed the grounds for objection to religious scruples.

In Britain, the term "closed shop" refers either to a shop that will hire only workers who are already union members or to a shop that requires newly hired workers to join the union. In the United States, the latter are called "union shops." See Smith, Trade Union Growth and Industrial Disputes, in Britain's Economic Perporasance 81, 86 n.6 (R. Caves \& L. Krause eds. 1980). "Union shops" are permitted under the National Labor Relations Act $\S 8(a)(3), 29$ U.S.C. $\$ 158(a)(3)(1982)$. 
ions and their members enjoyed a range of legal immunities unknown in other Western countries. In this section of the paper, I first outline the historical development of trade-union immunities and then suggest why, in view of the initially weak position of labor in the political process, the unions were able to obtain such legalized advantages.

\section{A. British Labor Laws, 1871-1976}

At common law, organized trade-union activities were likely to give rise to criminal prosecution for such offenses as obstruction, molestation, intimidation, and conspiracy. ${ }^{6}$ This legal background made the use of the strike weapon unappetizing. The Trade Union Act of 1871 (the 1871 Act) $)^{7}$ and the Conspiracy, and Protection of Property Act of 1875 (the 1875 Act), ${ }^{8}$ however, sharply curtailed the application to union activities of criminal laws forbidding such acts as conspiracy in restraint of trade ${ }^{\theta}$ and breaking contracts of employment. ${ }^{10}$ As the criminal law became less relevant to tradeunion activities, the arena of dispute shifted to the civil side. Participants in a strike could still be held liable in tort for conspiracy $^{11}$ or for inducing breach of the employment contracts of striking workers. ${ }^{12}$ The availability of civil remedies to limit tradeunion activities was confirmed by the the House of Lords in the Taff Vale Railway case, ${ }^{13}$ decided in 1901, which established that neither the 1871 Act nor the 1875 Act made trade-union organizations immune from suits for damages. ${ }^{14}$

One effect of Taff Vale was to rally workers to the newly

sost of the discussion in the text is drawn from the excellent account of British labor-law history found in Trads Union Immunities, supra note 1, at 11-26.

- Trade Union ImMUNITIES, supra note 1, at 11-12; see, e.g., Reg. v. Druitt, 10 Cox 592 (C.C. 1867) (obstruction, molestation, intimidation); Hornby v. Close, [1867] 2 Q.B 153 (restraint of trade); Reg v. Hewitt, 5 Cox 162 (Q.B. 1851) (criminal conspiracy).

334 \& 35 Vict., ch. 31.

- 38 \& 39 Vict., ch. 86.

- 34 \& 35 Vict., ch. $31, \S 2$.

10 38 \& 39 Vict., ch. $86, \S 17$ (III).

11 See, e.g., Temperton v. Russell, [1893] 1 Q.B. 715; see also S. WrBB \& B. WRBB, INDUSTRIAL DEMOCRACY 859-62 (1897) (contemporary discussion of civil liability for engaging in strike activity).

12 See, e.g., Quinn v. Leathem, 1901 A.C. 495; Allen v. Flood, 1898 A.C. 1; Temperton v. Russell, [1893] 1 Q.B. 715.

13 Taff Vale Ry. v. Amalgamated Soc'y of Ry. Servants, 1901 A.C. 426. The social impact of the case is discussed in S. WrBB \& B. WRBB, The History or Trade Unionism 60004 (rev. ed. 1926).

141901 A.C. at 438 (Lord Macnaghten). 
formed Labour Party. ${ }^{15}$ In 1903, the Conservative Government responded to trade-union pressure by setting up a Royal Commission, which ultimately reported in 1906 to a new Liberal Government that had taken office with a mandate for trade-union reform. ${ }^{16}$ The Liberal Government quickly enacted the Trade Disputes Act of 1906 (the 1906 Act), ${ }^{17}$ which established the basic framework of immunities within which the law of industrial actions was to operate over the following seventy-five years. ${ }^{18}$ It provided unions with immunity from liability for the torts of conspiracy, ${ }^{10}$ inducing breach of contract, ${ }^{20}$ and interference with trade, business, or employment, ${ }^{21}$ so long as the alleged acts were taken "in contemplation or furtherance of a trade dispute."22 Further, the 1906 Act overturned Taff Vale by providing trade-union corporate funds with absolute immunity from judgments for damages. ${ }^{23}$

Further immunities were granted under the Trade Disputes Act of 1965 (the 1965 Act), ${ }^{24}$ which provided that a threat to break

15 S. WeBB \& B. WeBB, supra note 13, at 604.

16 Report of the Royal Comatssion on Trade Disputes and Trade Combinations, CMD. No. 2825 (1906) [hereinafter cited as 1906 REPORT].

${ }^{17} 6$ Edw. 7, ch. 47, repealed by Industrial Relations Act, 1971, ch. 72. The Industrial Relations Act of 1971 was itself repealed in 1974. See infra notes 30-32 and accompanying text.

18 In 1914, the eminent legal authority, A.V. Dicey, lamented the damage inflicted upon English common law by this sequence of legislative interventions:

The current of opinion had for between thirty and forty years been gradually running with more and more force in the direction of collectivism, with the natural consequence that by 1900 the doctrine of laissez faire, in spite of the large element of truth which it contains, had more or less lost its hold upon the English people. . . . [T] interference by the State which had long prevailed in England had, to state the matter very moderately, lost much of its influence, and . . . the belief in the unlimited benefit to be obtained from freedom of contract had lost a good deal of its power.

A.v. Dicey, Lectures on the Relation Between law \& Public Opinion in England xxxxxxi (2d ed. 1914) (citations omitted).

10 $6 \mathrm{Edw} .7$, ch. $47, \S 1$.

so Id. \& 3.

1 Id.

$22 I d$.

23 Id. \&4.

24 Trade Disputes Act, 1965, ch. 48. During a weak period for the British labor movement, following the failure of the General Strike of 1926, see Trade UNION IMmUNITIES, supra note 1, at 16, the immunity of trade unions from criminal prosecution was partially removed. The Trade Disputes and Trade Unions Act of 1927 (the 1927 Act), 17 \& 18 Geo. 5, ch. 22, reintroduced criminal liability for inciting strikes not involved with a trade dispute, id. $\S 1(1)(a)$, and narrowed the definition of a "trade dispute" to cover only disputes between employers and employees over terms of employment or conditions of labor, id. § 1(1)(a)(a). The 1927 Act also imposed criminal liabilities upon employers for lockouts not pursuant to a trade dispute. Id. \& 1(1)(b). When the Labour Party came to power in 1945, it won the repeal of the 1927 Act, see Trade Disputes and Trade Union Act, 1946, 9 \& 10 Geo. 6 , ch. 52, thus reintroducing criminal immunity for labor-organizing activity not directly 
a contract of employment or to induce breach of such a contract was not actionable in tort. At the same time, however, the Labour Government also established a Royal Commission to investigate unions and employers' associations. The Commission reported that the system of legal immunities protecting trade unions had become a "legal maze." In response to the report of the Commission, the Labour Government issued a White Paper ${ }^{26}$ endorsing the Commission's proposal that British labor law be rationalized. ${ }^{27}$ The White Paper also proposed establishment of an administrative commission on industrial relations, registration of labor unions and employers' associations, compulsory voting prior to official strikes, amenability of unions to judgments in tort except in connection with a trade dispute, and other measures designed to make British labor law a more coherent scheme. ${ }^{28}$ These proposals were withdrawn following strenuous opposition from the Trades Union Congress. ${ }^{29}$

The Conservatives took power in 1970 and moved to undertake a sweeping overhaul of labor law, following some of the recommendations contained in Labour's White Paper. ${ }^{30}$ These changes met with a hostile reception from the majority of trade unions. The Trades Union Congress took a position of total noncooperation with the new legislation, leading to the imprisonment of some workers. ${ }^{31}$ The Labour Government that took office in 1974, however, won repeal of the Conservatives' legislation. The Trade Union and Labour Relations Act of 1974 (the 1974 Act) $^{32}$ in essence reestablished the system of immunities provided by the 1906 and 1965 Acts. In 1976, the Trade Union and Labour Relations (Amendment) Act (the 1976 Act) ${ }^{39}$ extended immunity to liability for the breach of all contracts, whether or not related to employment, so long as the acts from which liability was alleged to have arisen were accomplished "in furtherance of a trade dispute."

tied to narrowly defined "trade disputes."

${ }^{28}$ Report of the Royal Commission on Trade Unions and Employkrs' Associations, CMD. No. 3623, at 235 (1968).

26 First Secretary of State and Secretary of State for Employmgnt and Productivity, In Place of Strife: A Policy por Industrial Relations, Cmd. No. 3888 (1969).

17 Id. at 30.

2s Id. at 36-37.

3. Trade Union Immunities, supra note 1 , at 19.

so Industrial Relations Act, 1971, ch. 72 (repealed by Trade Union and Labour Relations Act, 1974, ch. 52).

31 Trade Union Immunities, supra note 1, at 20.

3s Trade Union and Labour Relations Act, 1974, ch. 52.

3s Trade Union and Labour Relations (Amendment) Act, 1976, ch. 7. 
Finally, whatever limits might have been imposed upon tradeunion immunities by the "in furtherance of a trade dispute" language were neutralized by the House of Lords in Express Newspapers, $L t d$. v. McShane ${ }^{34}$ which held that "in furtherance of a trade dispute" implied a subjective test and thus that it was a sufficient defense under the 1976 Act to show that the perpetrator of the union action honestly thought that such action might further a trade dispute. ${ }^{38}$ With this decision, British trade-union immunities became all-extensive, with implications for labor-market behavior during the early months of 1979 that eventually hounded the Labour Government out of office.

\section{B. British Trade Unions and the Power of Collective Action}

British labor laws during the period from 1871 to 1976 granted to trade unions and their members the right to a closed shop along with an elaborate system of immunities from the ordinary legal process. By 1976, this scheme rendered the British trade-union movement the most powerful in the Western world. ${ }^{36}$ Yet this position of power was achieved from a minority position in the electorate against apparently influential employer interests.

The political successes of the British trade unions are perhaps best explained by application of the theory of pressure-group power developed in Mancur Olson's The Rise and Decline of $\mathrm{Na}$ tions. ${ }^{37}$ It must be remembered, after all, that the sweeping legal immunities achieved by British trade unions arose neither by judicial development of legal doctrine nor by the establishment of a comprehensive administrative machinery such as the one that exists in the United States. The successes of the British trade unions came directly from the ballot box. ${ }^{38}$

\footnotetext{
s4 1980 A.C. 672 , [1980] 1 All E.R. 65.

ss Id. at 686, [1980] 1 All E.R. at 72 (Lord Diplock).

${ }^{36}$ Cf. Trade Union IMmunities, supra note 1 , at 25 :
}

[I]t has been suggested that the immunities now allow too wide a scope for industrial action without due regard to its consequences. No one in 1906, for example, could have foreseen how damaging the scope for organising secondary industrial action would become as a result of the interdependence of modern industries and improved communication; nor indeed how the balance of bargaining power would tip in favour of trade unions.

s7 Mancur Olson, The Rise and Decline of Nations 17-74 (1982).

ss The history of pre-1971 trade-union legislation illustrates this fact. Each of the four major pieces of labor-market legislation granting or extending immunity to unions (the $1871,1875,1906$, and 1965 Acts) was preceded by one or more court decisions that were thought to jeopardize the trade-union position. Examples include Hornby v. Close, [1867] 2 Q.B. 153, which held that members of a tradesmen's society that gave funds to encourage 
Olson has emphasized that the result of successful collective or group action is a collective or public good ${ }^{39}$ available to all members of the group quite apart from the extent of their individual contributions. Thus, members of a common-interest group are not necessarily fully motivated to serve it and may become free riders on the efforts of other members. If the group is sufficiently large, there may be enough free riders to cause the collective effort to collapse.

On this basis, Olson argues that the collective interest of large special-interest groups, such as individual trade unions or the trade-union movement as a whole, can be served only if there is coercion of the members or some additional incentive apart from the achievement of the collective good. Even when coercion or other incentives are potentially available, organizing a special-interest group for the first time is difficult and requires creative leadership and favorable conditions. Further, since identification of strong collective interests is always difficult, stable and relatively homogeneous societies with settled boundaries, such as Britain, ${ }^{40}$ are most amenable to collective action and pressure-group politics. The ingredients of pressure-group success described by Olson-stable social organization, good initial leadership, coercion of membership, and provision of private benefits-all appear to have contributed to the rise of trade-union power in Britain since the mid-nineteenth century.

and relieve men on strike were criminally liable for restraint of trade; Regina v. Bunn, 12 Cox 316 (C.C. 1872), the "gas-stokers' case," which held that employees who breached their employment contracts to protest the dismissal of a fellow worker were criminally liable for conspiracy to obstruct trade; Taff Vale Ry. v. Amalgamated Soc'y of Ry. Servants, 1901 A.C. 426 (discussed supra text accompanying notes 13-14); and Rookes v. Barnard, 1964 A.C. 1129, [1964] 1 All E.R. 367, which held that a threat to strike in breach of an employment contract constituted the common law tort of intimidation.

On three occasions (in 1867, 1875, and 1903) a Royal Commission had been created to recommend changes in the law, and on a fourth (1965) a commission was created at the same time that the law was changed. These commissions, however, were not the principal vehicles for enactments favorable to the trade unions. Indeed, two of them were boycotted by the trade unions, none produced a unanimous report, and in no case did the resulting legislation follow the recommendations of the majority report. In the two cases where unions boycotted the inquiries, the ensuing legislation satisfied union demands in full. The trade unions clearly relied on their direct access to the legislature-even to Disraeli's Conservatives, who enacted the 1875 Act. See generally C.G. Hanson, Trade Unions: A CenTURY or PrIVILEge? (1973).

39 The term "public good" is used in its technical sense. It may in fact be a "public bad," as Olson recognizes: "A labor union, for example, sometimes has an incentive to repress a labor-saving innovation that would reduce the demand for the workers it represents, or to demand featherbedding or overmanning." M. OLson, supra note 37, at 62.

40 Id. at 38-41. 
It appears that the first British trade unions were able to mitigate free-rider problems through their welfare-benefit programs, which were virtually the only form of social security available to workers during the nineteenth century. This was especially true of the craft unions, which dominated the trade-union movement during this period. Indeed, Robert Applegarth, who, as general secretary of the Amalgamated Society of Carpenters and Joiners, played a major role in shifting public opinion in favor of labor in the late 1860's, characterized welfare benefits in his testimony before the 1867 Royal Commission as the major contribution of the craft unions. ${ }^{41}$ Beatrice and Sidney Webb apparently were so impressed by Applegarth's statements that they incorrectly described his union in their History of Trade Unionism as primarily a national friendly society. ${ }^{42}$ Union welfare programs thus served two purposes at once. First, they helped to keep members aligned with the interests of the group by providing a private benefit available only to members. Second, they served to confuse legislators as to the true goals of organized labor. ${ }^{43}$ This was skillful leadership indeed, and largely through such leadership were the early immunities won from Parliament.

Of course, the legislative success of the unions would have been much less marked in the absence of franchise extensions during the latter half of the nineteenth century. The influence of even a relatively small number of trade unionists entering the electorate was leveraged by competition between the Liberals and the Conservatives to win the support of this new faction. As early as 1871, the Liberal Gladstone, although reluctant to support trade-union immunities, felt pressured politically to do so. By 1874, Disraeli's Conservative Government was overtly seeking out newly enfranchised voters with his policy of "Tory Democracy," and the consequence was the 1875 Act, ${ }^{44}$ which shielded trade unionists from the law of criminal conspiracy. Conditions at this time were therefore favorable to the carefully orchestrated pressures exerted on the political process by an adept trade-union leadership.

It is noteworthy that the cornerstone of trade-union immunity, the 1906 Act, $^{45}$ went directly counter to the recommendations

4 Applegarth skillfully directed attention away from the restrictive practices that were central to the trade unions' function. See C. HANSON, supra note 38, at 11-12.

$12 \mathrm{~S}$. WeBb. \& B. WeBB, supra note 13, at 233.

is See C. Hanson, supra note 38, at 13.

4438 \& 39 Vict., ch. 86 (discussed supra text accompanying notes 8-10).

45 See supra text accompanying notes 17-23. 
of the Royal Commission appointed in 1903 to reexamine British labor law. The Commission expressly supported the Taff Vale decision and recommended that unions be amenable to actions in tort. $^{46}$ The reaction to the 1906 Act by intellectuals favorably disposed to the trade unions was also negative. The Webbs, for example, wrote that the immunities granted by the 1906 Act were "extraordinary," "unlimited," and "monstrous."47 Yet the power of pressure-group politics held the field. The ability of trade-union leaders to minimize free riding and thus to strengthen their ability to maintain a consolidated power base is perhaps the most telling British evidence available in support of Olson's collective-action theory.

The existence of a powerful leadership raises several questions about the economic and political significance of British trade unions. In the next part of this paper I will argue that the unions' position of legal immunity encouraged union leadership to move from the economic to the political arena in order to capture further benefits for themselves at the expense of the common weal.

\section{Trade Union Immunities and Rent Seeking in British LABOR MARKETS}

Most trade unions are nonproprietary organizations, the leaderships of which are unencumbered by the monitoring that normally takes place in capital markets. That is, the union does not own physical property that the leadership must maintain at a value high enough to ward off competitive bidders. ${ }^{48}$ Monitoring of agents (the leadership) by principals (the rank-and-file) is therefore attenuated, both by the absence of a market in trade-union leaders and by a lack of incentives for voting members to take an active interest in the leadership election process. ${ }^{49}$ In such circumstances, the leadership itself and other powerful coalitions within the union-in Britain notably the shop stewards-are free to pursue objectives of either an economic or political nature, whether or not such objectives have the approval of the rank-and-file.

Trade unions are correctly viewed as labor cartels, ${ }^{\text {s0 }}$ the prin-

46 1906 REPORT, supra note 16 , at 2.

4 S. WEBB \& B. WEBB, supra note 13 , at 606 .

4s For a discussion of monitoring in the capital markets, see Manne, Mergers and the Market for Corporate Control, 73 J. PoL. Econ. 110, 112-14 (1965).

- For a useful general discussion of the principal/agent problem, see Fama, Agency Problems and the Theory of the Firm, 88 J. PoL. EcoN. 288 (1980).

so See Posner, Some Economics of Labor Law, 51 U. CHI. L. Rev. 988, 989 (1984). 
cipal objective of which is to transfer wealth from employers to employee-members. This behavior is referred to technically as "rent seeking." It should be noted that the mere transfer of resources from employer to employee does not necessarily prevent the optimum allocation of resources: self-interested behavior may itself result in some form of optimum distribution, and such behavior cannot be eliminated in any event. The term "rent seeking," however, is used specifically to describe behavior in institutional settings where individual efforts to appropriate wealth generate social waste rather than surplus. ${ }^{52}$ The British institutional setting was altered by the 1906 Act and its successors in such a way that self-interested behavior was transformed into rent seeking in this pejorative sense. Such rent-seeking behavior has been a direct result of the overly broad discretion vested in union leadership by virtue of (a) a lack of monitoring of agents by their principals, (b) the general apathy of the rank-and-file, and especially (c) the opportunity created by legal immunities to exercise coercive political power.

\section{A. The Failure of Monitoring}

The special legal privileges of British trade unions-notably their legal immunities, the closed shop, and the absence of compulsory secret balloting of members on important policy issues-have contributed to a principal/agent problem ${ }^{53}$ that has facilitated significant rent seeking by union leaders. British trade unions are nonproprietary organizations in the sense that members neither hold private property rights in their membership status nor own alienable rights to the net assets of the organization. For the most part, they are subject to "no raiding" agreements that severely impede interunion competition and virtually eliminate leadership mobility among unions. ${ }^{54}$ In these respects, they are similar to trade unions in the United States and Western Europe, with which they share a number of common problems.

${ }^{31}$ A general discussion of rent seeking is provided by Buchanan, Rent Seeking and Profit Seeking, in Toward a Theory of the Rent-SeEking Society 3 (J. Buchanan, R. Tollison \& G. Tullock eds. 1980).

${ }^{52}$ Id. at 4.

ss For an excellent discussion of this concept in the trade-union context, see Martin, The Agency Problem in a Nonproprietary Theory of Union Behavior, in The Economics op Trade Unions: New Directions 191, 201-11 (J. Rosa ed. 1984).

st For a discussion of "exit" problems, see Burton, The Economic Analysis of the Trade Union as a Political Institution, in The Economics of Trade UnIons: New DirecTIONS 123, 145-46 (J. Rosa ed. 1984). 
Labor unions in general depend for their success on attracting large numbers of members willing to commit resources to the organization (the objectives of which they may, of course, wish to shape). These investments take the form of initiation fees, dues assessments, and the expected income foregone during strikes and picketing. Members require a net return on these investments in the form of positive wage-and-benefit differentials between unionized and nonunionized labor markets. In this sense, members may be viewed as residual claimants, the counterparts of corporate shareholders. Since these residual claims are distributed among large numbers of individuals, usually without reference to their relative contributions to the rent-seeking exercise, individual members have an incentive to shirk in this activity. The potential for widespread shirking generates a demand for monitoring services in the form of management agents equipped with disciplinary weapons such as the power to expel, fine, or demote in seniority those who shirk. Union management is also expected to provide other services, notably in obtaining information concerning collectivebargaining opportunities and in negotiating and policing collectivebargaining agreements. The effective execution of these tasks requires specialized skills and managerial discretion similar to that typically exercised by senior corporate executives.

The nontransferability of membership rights, however, precludes two sources of control or influence over managerial behavior that are available to stockholders in proprietary firms. First, members cannot simply withdraw their "capital" from the firm, as a corporate shareholder might effectively do by selling his shares in response to undesirable leadership policies. Second, voting power cannot be concentrated in a few large individual "shareholders" for the purpose of changing management personnel. More important, the limited nature of an individual member's claim to rents, measured against the primarily collective nature of the gains obtainable from monitoring an errant leadership, greatly reduces the return that individual members can obtain by engaging in such monitoring. This is so because of a free-rider problem. Those who monitor at their own expense will produce gains for all members in the form of a more efficient leadership; but since the benefit of better leadership will accrue to members who have not shared in the cost of producing it, those who pay for monitoring cannot realize the full value of their investment. They will thus tend to avoid 
monitoring altogether. ${ }^{\mathrm{s5}}$ In consequence, the nonproprietary character of most unions provides greater opportunities for union management (in contradistinction to the managers of proprietary firms) to pursue its own interests at the expense of the interests of the rank-and-file.

Another source of leadership discretion is the lack of a market in union managers, who tend to come from apprenticeship programs in a given trade and to form loyalties within that trade. They tend not to move from one union to another on the basis of sheer managerial skills. It is probably less likely that the leader of the steelworkers would be hired to manage the dockworkers' union than that the chairman of a steel-producing corporation would become the chairman of a shipping corporation. Union management may even possess life tenure. Although the potential threat posed by reform candidates within a union will exert some discipline on the incumbents, the existing leadership usually can protect itself through its control of channels of information, through its ability to manipulate voting procedures, and by virtue of membership apathy. In general, therefore, the tenure of officials in nonproprietary unions will tend to be longer, and the frequency of contested elections lower, than in proprietary organizations.

Divergence of interest between agents and principals is also a predictable outcome of differences in their compensation schemes. The leaders and the rank-and-file are alike in lacking negotiable rights to their union cards or to the perquisites of office. Typically, however, the leaders are employed on fixed-salary contracts, which may reflect rents expected or obtained in the past but which do not allow the leaders to benefit in step with the-quality of present performance. Ceteris paribus, the leaders will divert resources away from economic rent seeking for the benefit of members toward the pursuit of personal goals. Since the average member would not support such a diversion, the leaders will attempt to forestall objections by controlling the flow of information. Policies that increase membership size and raise the dues income on which leadership perquisites are seen to rest will be pursued even where rent loss to the collective membership results. Managers may even pursue policies that earn union leadership the gratitude of government or corporate management, whether that gratitude is expressed in current or expected income transfers. Examples include so-called "sweetheart contracts" that suppress wage rates below

M. OLson, supra note 37, at 18. 
otherwise attainable levels. ${ }^{.6}$

By itself, therefore, the principal/agent problem may turn out to enhance general social welfare in nonproprietary union systems by depressing the level of rent-seeking activity below its attainable outer bound. In countries where union action is tightly constrained by law to "trade dispute" issues and where union funds are placed at risk by unlawful action, union management is unlikely to engage in outrageously excessive rent seeking or to pursue consistent policies designed to harm the wealth-producing potential of the employers with whom they contract.

\section{B. Apathy of the Rank-and-File}

In Britain, legal immunities have combined with other historical factors to increase the apathy of the rank-and-file and to open the door to significant wealth-destructive rent seeking by the leadership. The immunities themselves have been one important source of apathy. The absence of a threat either to union funds or of criminal penalties, the absence of legally binding collective-bargaining contracts, and the freedom of unions to engage in "industrial action" far removed from "trade disputes"s7 all combined to promote membership apathy towards leadership selection: there was no reason for union members to fear direct and immediate damage from the irresponsible acts of their agents. In the case of public-sector unions, there was not even a risk that the employer would go out of business and, before 1975, little risk of loss of jobs. $^{58}$ In such circumstances, apathy was significant and membership voting rates in management elections were low. Once "elected" into office, in some cases on lifetime contracts, the union leadership was vested with significant discretionary power.

Another important source of apathy in the rank-and-file is the large size of the membership group. The divergence of interest between leadership and the rank-and-file causes the leadership to push union membership to a size larger than is beneficial to the average member. The leaders' discretion tends to increase with the size of the union (because monitoring by members becomes more difficult), while the members' interests would best be served by

s6 Many such arrangements were exposed during the McClellan hearings in the United States during the 1950's. See Rrport op Senate Sklgct Comm. on Impropkr Activitiss in THE Labor or Management Figld, S. REP. No. 1417, 85th Cong., 2d Sess. 4 (1958).

${ }^{37}$ See supra notes 34-35 and accompanying text.

ss Rowley \& Yarrow, Property Rights, Regulation and Public Enterprise: The Case of the British Steel Industry 1957-1975, 1 INT'L Rgv. L. \& Econ. 63, 64, 68 (1981). 
halting growth at the point where per capita rents are greatest. Large size therefore promotes apathy and increases the scope of management discretion in a vicious circle.

The problem of large size can be illuminated by applying the economic theory of clubs. ${ }^{59}$ Unions, because they are nonproprietary, are like clubs. Membership dues are their principal source of revenue. They produce a flow of services for their members, and they are usually able to exclude nonmembers from such benefits. ${ }^{60}$ Unions, however, tend in practice not to exclude non-dues-paying members completely from the benefits they provide, even where the law allows them to do so, as it does in Britain. To do so would be to encourage nonmembers to undercut cartel rents to the longterm damage of the club. ${ }^{61}$ Thus, approximately fifty percent of the British work force is unionized, ${ }^{62}$ but union contracts cover some three-quarters of all employees. ${ }^{63}$ Noncontributors could lawfully be excluded, but only at the unacceptable cost of eroding membership size and the rents accruing to the club membership-factors that become important when evaluating union rent seeking in the political marketplace.

As I have noted, the union-club is unlikely to be operated exclusively in the membership's interest, given the principal/agent problem and the consequently high degree of leadership discretion. Generally, the larger the membership size, the greater the degree of the leaders' discretion because individual members have less incentive to monitor the leaders. ${ }^{64}$ Indeed, in very large unions, the so-called "paradox of voting" arises in much the same way that it does in stockholder votes, where no voter could expect his vote to make a difference in the outcome and there is consequently a disinclination to vote. ${ }^{65}$ For this reason, union leadership may press for a legal climate that allows it to increase union membership size

so See generally Buchanan, An Economic Theory of Clubs, 32 Economica 1 (1965). An excellent study of the trade union as a political/club entity is contained in Burton, supra note 54 , at $140-51$.

${ }^{\circ}$ In some countries there are legal provisions to the contrary. See, e.g., National Labor Relations Act § 9(a), 29 U.S.C. \& 159(a) (1982) (union shall represent all employees within a bargaining unit).

e1 See Mancur Olson, The Logic of Colnective Action 41 (1965) (discussing the ability of holdouts to destroy cartel rents).

as Metcalfe \& Richardson, Labour, in ThE U.K. EconomY 223, 267 (7th ed. 1978).

as Id.

- See supra text following note 58.

es See M. OLson,' supra note 61, at 55 (discussing low participation of stockholders in corporate voting). Stockholders, of course, unlike union members, can "vote with their feet" by selling their shares. 
at the expense of the interests of the average rank-and-file member.

In principle, alienated union members may exit from their union into the nonunion sector or into a union more congenial to their preferences. In practice, the opportunity to exercise either option must depend upon the nature of the labor market within which workers are employed. If the market is characterized by competing unions without interjurisdictional agreements, and if the closed shop is illegal (as in the United States ${ }^{66}$ ), the exit opportunity is available at relatively low personal cost. Over time, member redistributions would eliminate the potential for leaders to exploit agency discretion. ${ }^{67}$ But if the labor market is tightly cartelized, with rigid interjurisdictional agreements and closed shops (as in Britain), the cost of exit will be high and the scope for discretionary leadership behavior correspondingly greater.

Frustration in exit may cause members to resort to a "voice" alternative, in the form either of direct participation in monitoring or of support for rival candidates for union leadership. As noted above, ${ }^{88}$ however, both of these devices tend to be hindered by the free-rider problem and the associated incentives for member apathy. Furthermore, the voice solution becomes increasingly problematic as union size grows, for the paradoxes of participation and voting imply that individual members have a minimal expectation of benefits from exercising voice in any large organization. ${ }^{69}$ Moreover, the incumbent always has significant built-in advantages in any election contest.

We must conclude that union leaders have both the incentive and the means to pursue a policy of rapid growth in the size of union membership, even at considerable cost to the membership's per capita rents. As the next section will show, however, this does not have the socially beneficial effect of reducing unions' rent-seeking behavior.

\section{Political Rent Seeking}

The pay scale for union leaders in Britain has not been high. This factor reduces the incentive for union leaders to seek rents in

-6 Trade UNION IMMUNITIES, supra note 1, at 109.

${ }^{67}$ See generally Buchanan \& Goetz, Efficiency Limits of Fiscal Mobility: An Assessment of the Tiebout Model, 1 J. PuB. Econ. 25, 27-28 (1972).

os See supra notes 55-56 and accompanying text.

- Furthermore, there may be significant personal costs to an individual who voices dissent: for example, ostracism, threats, and even physical harm. 
the economic, as opposed to the political, market. Indeed, the immunities sought by union leadership, which have broadened the concept of "trade disputes" far beyond employer/employee relations, are more likely to be of use in political than in economic rent seeking. In these peculiar circumstances, the hypothesis suggested above, ${ }^{70}$ that excessive wealth-destructive rent seeking typically will not occur through union action, does not hold true. The fulcrum of the "British disease"- a very low rate of economic growth in a highly developed, democratic nation ${ }^{71}$-can be traced in large part to political rent seeking by union leaders.

As a consequence of the principal/agent problem, trade-union leaders have a direct incentive to seek rents in the political market by shaping the legal environment to assist them in the attainment of their objectives. They may do so in several ways. First, they may enter the political process directly, as has happened in Britain, by financing a "captive" political party and by sponsoring a significant number of that party's candidates. In so doing, they may hope to restrict the range of positions taken by that party on relevant policy issues. Second, they may use their own voting strength to shift the range of positions taken by noncaptive parties and to establish the terms of public debate. Third, unions may concentrate their attention on public-sector industries, where the government itself is the employer, as a means of gaining political concessions. ${ }^{72}$ Each form of political rent seeking has occurred in Britain during the twentieth century.

At the beginning of the century, the British Trades Union Congress established a political party, the Labour Party, to represent its interests in Parliament. Subsequently, this party became one of the two largest in Britain. The unions provide funds for more than seventy-five percent of the Labour Party's general expenditures and for ninety-five percent of its expenditures at general elections. Unless union members specifically opt out of the political levy-and this "voice" option usually entails costly sacrifice in terms of peer-group status-the levy is deducted automatically and is spent at the discretion of the leadership. The unions contributed to the campaign expenses of over 125 Labour members in the last Parliament, out of a House of Commons with 625 seats. Unions nominate over fifty percent of Labour's national executive

${ }^{70}$ See supra text following note 56.

71 See M. OLson, supra note 37 , at 3.

${ }^{72}$ It should be recalled that such significant British industries as coal, steel, and automobile manufacture have been nationalized and are thus part of the public sector. 
committee, the Party's principal policy-formulating body. Through their block votes, union leaders control almost ninety percent of all votes of the Labour Party Conference, which is also important in policy formulation. Union leaders, through their block votes, now possess a forty-percent voice in the selection of the Leader and the Deputy Leader of the Labour Party itself. Union leaders thus exercise considerable influence over the policy positions of the Labour Party, not only with respect to labor-market policies, but more generally in any policy area of interest to them. Naturally, the value of such political influence attracts to the unions' leadership individuals who are intent on political as well as pecuniary objectives.

Union leaders also exert influence on the political process by virtue of the size of their overall membership, which is just under fifty percent of the total labor force, ${ }^{73}$ even though some forty percent of union membership is believed to vote most often for Conservative candidates. No vote-seeking political party can ignore the preferences of such a significant portion of the electorate. Of course, to the extent that union leaders' preferences diverge from those of the membership, the leaders' political influence depends upon effective propaganda within the political process. The greater media coverage afforded to union leaders than to their members assists the former in this exercise. ${ }^{74}$

As unions become larger, they will be more successful in lobbying for further legislation and regulation favorable to their monopoly status. ${ }^{78}$ Larger unions will want more government regulation, partly because private cartelization is more costly to members than government regulation and partly because a cartel is more difficult to maintain as the group increases in size. Larger unions will better be able to obtain such government regulation as their voting strength increases. Most especially will favorable regulation be forthcoming in the case of large public-sector unions, since gov-

72 Cencral Orfice or Inpormation, Trade Unions 5 (1977).

74 The ability of British trade unions to act as effective pressure groups might tend to be eroded as their size grows. Mancur Olson's collective-action analysis suggests that the effectiveness of large groups is hampered by both free riders, M. OLson, supra note 61, at 48 , and holdouts, id. at 41 . Olson points out that any one nonparticipant may be able to capture for himself the benefits created by group collusion. It follows from this that the larger the collective good, the greater the incentive to hold out and appropriate it. In Britain, however, these problems are minimized by the operation of the legally sanctioned closed shop, which allows unions to grow much larger than pressure groups that cannot exclude nonmembers from sharing in the benefits they obtain.

7t See Stigler, The Theory of Economic Regulation, 2 BeLt J. Econ. \& MgMt. Sct. 3 (1971). 
ernments usually have a vested interest of their own in monopoly solutions within nationalized industries.

British trade-union history is consistent with these predictions. The so-called "new model" unions that established themselves in the mid-nineteenth century were composed primarily of skilled craftsmen who pursued rents by cartelizing private markets, restricting membership to apprenticed craftsmen, and charging high membership dues. ${ }^{78}$ Their interest in electoral politics was insignificant. With the emergence of the large unions of lower-paid, unskilled workers after 1889 , however, trade-union penetration of the political process increased sharply. By 1900, the labor group in Parliament was already established. Thereafter, politics became an increasingly important focus of large-union activity. For example, in 1920, the effort of the British cabinet to send munitions to Poland for use against Russia was stymied by the threat from organized transport workers to refuse to load the arms on board ship. ${ }^{77}$ In 1926, the trade-union movement called a general strike in an attempt, though an unsuccessful one, to force a political reversal of wage cuts in the coal-mining industry. ${ }^{78}$

Thereafter, collective union action became a force that no government could ignore. Between 1968 and 1979, union action assumed disturbing political dimensions. In 1969, opposition from the unions and from union-sponsored members of Parliament forced Prime Minister Harold Wilson to abandon industrial-relations reforms to which he was publicly committed. ${ }^{79}$ In 1971 , the Industrial Relations Act, ${ }^{80}$ enacted by a Conservative Government, was strongly resisted by the unions: ${ }^{81}$ its application was obstructed by illegal behavior and, in 1974, it was repealed following the electoral defeat of the Conservatives in the wake of a three-day work week imposed to conserve fuel during a prolonged miners' strike. In the mid-1970's, the Labour Government, fearful of tradeunion power, entered into the so-called "Social Contract" with the unions, offering them a direct voice in policy formation. The unions used this power to consolidate the closed shop, increase job tenure, and widen the scope of permissible secondary-strike activity. Having achieved these objectives, the unions abandoned the

\footnotetext{
${ }^{78}$ See S. WeBB \& B. WEBB, supra note 13, at 217-18.

77 Henry Pelling, A History of British Trade Unionism 164 (1963).

78 Id. at 173-75.

79 See supra text accompanying notes 26-29.

so Industrial Relations Act, 1971, ch. 72.

s2 See supra note 31 and accompanying text.
} 
Social Contract in 1978 and, during early 1979, engaged in the most extensive sequence of strike activity ever witnessed in the United Kingdom.

The consequence of this disruption was the defeat of the Labour Government in May 1979 and the election of a Conservative Government committed to anti-union legislation. Despite this defeat, however, unions have continued to exert their political power successfully. In February 1981, an unofficial coal strike forced the government to abandon the phaseout of public subsidies to uneconomic coal pits. Faced with the threat of a strike by water workers in 1980 and 1981, the government breached its public-sector pay policy. In 1983, when the water workers struck, the government capitulated to their pay demands. Both examples involve mass unions of semiskilled workers in public-sector occupations where heavy regulation prevents competitive solutions.

As this history indicates, British unions have exercised increasingly significant political power, ${ }^{82}$ with which they have shaped public policies to their own advantage. The effects on the rest of the British economy are examined in the next section of this paper.

\section{Macroeconomic Implications of Rent SeEking In the BRITISH LABOR MARKETS}

A comprehensive analysis of the economic implications of rent seeking by British labor unions is beyond the scope of this paper. In this section I will discuss some of the more important ways in which social wealth has been destroyed.

\section{A. Strikes and Productivity}

One area in which wealth-destructive behavior is evident is in the very high incidence of unofficial strikes. ${ }^{83}$ These are largely a product of trade-union immunity from the laws of contract and tort, $^{84}$ buttressed by the strict application of closed-shop rules.

s2 Unions' political power, while still great, seems to have declined since 1979. See infra notes 100-06 and accompanying text.

*3 See Trade Union ImMUNITIEs, supra note 1, at 5:

A shift of power has been taking place in the trade union movement; from the centre to the shopfloor, from full-time officials of the unions to shop stewards drawn from those among whom they work. It is reflected in the tendency for plenary power to call industrial action, negotiate and settle to be seized by the shopfloor or delegated to it. . . . It has been associated with an increase in unofficial industrial action to the extent that some 90 percent of strikes are now unofficial.

st See id. at 29 ("[I]f trade unions were made financially responsible . . . they could be 
More than ninety percent of strikes in Britain are unofficial, ${ }^{85}$ and this has been a consistent feature of British industrial relations since the 1950's. The absence of legally enforceable collective-bargaining agreements does not necessarily imply that more working days are lost to strikes, but it does cause strikes to be dispersed away from the period of contract renegotiation. ${ }^{86}$ For example, the number of work days per person lost through strikes is about equal in Britain and the United States, but ninety percent of American strikes are concentrated around the period of renegotiation. ${ }^{87}$ This is a major advantage in reducing uncertainty, and it enables American industrial management to center attention upon wealth creation (rather than upon labor relations) during the span of the contract.

A second area in which strikes have been used in a wealthdestructive manner in Britain is in secondary industrial actions against employers who are not party to a trade dispute. Such action may take the form of a strike or of refusing to handle ("blacking") goods going to and from the employer involved in a dispute. During the 1970's, with the growing strength of trade unions, secondary action was increasingly used, not to put commercial pressure on the employer of striking workers, but indiscriminately, in both official and unofficial disputes, to inflict damage on the economy and thus to put pressure on the community as a whole. ${ }^{88}$

This development was stimulated in particular by the immunity for inducement to break any contract conferred by the 1976 $\mathrm{Act}^{89}$ and confirmed by the House of Lords in late $1979 . .^{90}$ The first major dispute following the Lords' decision-the national steel strike of early 1980 - was characterized by extensive secondary action, including blacking by dock workers, railway men, and lorry drivers and the calling out on strike of employees in the private steel sector who were not involved in the dispute and who in many cases did not desire to strike. ${ }^{91}$ Closely associated with secondary

expected in their own interest to exert greater internal discipline over their officials and members, particularly in respect of unofficial action . . . ."). In 1981, the Secretary of State for Employment concluded that the abolition of immunities would reduce the incidence of unofficial strikes in Britain. Id. at 33.

ss Id. at 33 .

ss Id. at 55 .

87 Id.

ss Id. at 37-38.

82 Id. at 38; see supra note 33 and accompanying text (discussing the 1976 Act).

so Express Newspapers, Ltd. v. McShane, 1980 A.C. 672, [1980] 1 All E.R. 65; see supra notes 34-35 and accompanying text.

91 Trade Union ImMunites, supra note 1, at 38. 
industrial action was the growth during the 1970's of secondary picketing, ${ }^{22}$ which until 1980 was also protected under union immunity. Even when such picketing involved intimidation and was therefore unlawful, penalties rarely were sought and damages rarely were claimed.

Productivity statistics show that this kind of union behavior destroys wealth. In an attempt to isolate the role of trade unions in the British labor-productivity deficit, Clifford Pratten undertook, in 1976, a comparative study of labor productivity in the British and overseas factories of international companies (where absolute levels of labor productivity might be expected to be comparable because of similarities of product and technology). He collected comparisons from one hundred companies and calculated percentage differentials between Britain and ten other industrial countries. The United States had a fifty-percent advantage, France a fifteen-percent advantage, and West Germany a twenty-seven-percent advantage. ${ }^{93}$

Pratten further sought to assess the contribution of "behavioral" factors, such as strikes, restrictive practices, and overmanning, to the overall productivity differentials. His results suggest that labor difficulties accounted for more than one-fifth of the British shortfall relative to the United States, one-third of that relative to France, and approximately one-half of that relative to West Germany. ${ }^{94}$ This research offers some insight into the orders of magnitude involved, which appear to be significant even if one allows for managerial complicity in the behavioral effects.

\section{B. Artifical Wage Inflation}

Labor-market theory suggests that unions cartelize labor in order to provide a positive union/nonunion wage differential for workers with comparable skills and job attributes. ${ }^{95}$ Their ability to accomplish this rests on two kinds of economic power that, although related and reinforcing, are analytically separable. ${ }^{96}$ The long-term monopoly power of a trade union is derived from its

Id. at 42.

a Clifford Pratten, Labour Productivity Differentials Within International Companirs 5 (1976).

ot See id. at 61.

25 See Johnson, Changes over Time in the Union-Nonunion Wage Differential in the United States, in The Economics of Trade Unions: New Directions 3 (J. Rosa ed. 1984); see also Addison, $A$ Comment on Johnson, in id. at 20.

* See Burton, A Comment on Reder, in The Economics of Trade Unions: New DirecTIONs 38 (J. Rosa ed. 1984). 
ability to restrict supply or to prevent entry into a labor market by, for example, enforcing lengthy apprenticeship programs or issuing a limited number of union cards or licenses in the closedshop environment. Such a constriction of supply induces an unambiguous market response: the price of such labor is elevated above the competitive level.

In addition, however, unions possess a short-term power to constrict the supply of labor through their ability to call strikes. This power rests upon the ability of unions to withhold labor in such a manner that it imposes costs upon employers and customers by disrupting the marketplace. The ability of the British employer to replace striking workers is severely limited by both the legal immunities afforded to striking workers and by the de facto permission granted by the courts ${ }^{97}$ for strikers to harass strikebreakers and their employers. Because only unionized workers can strike effectively, the cost of replacing strikers drives a wedge between the cost of employing nonunion workers and the cost of employing otherwise identical union workers. In essence, unionization confers on workers a nontransferable right to obtain a premium wage through the threat of strike behavior. The only condition for this right is union membership.

In order to avoid such adverse outcomes, employers might seek to protect themselves by requiring, as a condition of employment, that workers agree not to join unions; alternatively, employers might select workers who are believed to be adverse to unionization. In Britain, the law prohibits the former solution and frowns upon the latter. In such circumstances, the union/nonunion wage differential should be positive and significant, as a consequence of the disruption (actual or potential) of market relationships.

If unionization raises wage rates (and therefore commodity prices to consumers) above the competitive market level, a question remains as to why consumers fail to substitute into the nonunionized sector. If such substitution were widespread, the union wage could not in the long run exceed the nonunion wage. To avoid this outcome, unions must be able, through either closed-shop restrictions or a statutory monopoly at the employer level, to prevent consumers from switching to nonunionized products. In Britain, the closed shop is widespread, having been encouraged by legislation during the 1970 's. ${ }^{98}$ The public sector, with its statutory monopolies in nationalized industries, is also extensive. Furthermore,

97 See supra notes 34-35 and accompanying text.

so See supra note 4. 
unions are motivated to press for a wide range of restrictions on foreign competition. The environment is conducive, therefore, to the achievement of positive union/nonunion wage differentials over a wide range of commodities and to political intervention by unions as a major rent-seeking and rent-maintenance activity.

Evidence concerning union/nonunion wage differentials in Britain supports this analysis. Data show a widening union/nonunion wage gap in Britain between 1968 and 1975, a period during which union power increased by virtue of broadened immunities and the increasing role of the public sector in industry. ${ }^{90}$ Such data do not, of course, discriminate between the long-run and short-run effects of union monopoly power, but the legislation of the 1970's arguably exerted the greater impact on the short-run strike effect. In any event, the evidence of union/nonunion wage differentials suggests the existence of significant union rents.

\section{Post-1979 REFoRMS}

I have established that the legal immunities granted to British trade unions helped create a climate of political rent seeking and wealth destruction. In the period since the Conservatives came to power in 1979, the Thatcher Governments have followed a step-bystep approach to reform, in contrast with the failed attempt at total overhaul in $1971 .^{100}$

The Employment Act of 1980 (the 1980 Act) ${ }^{101}$ restricted the immunities conferred upon trade unions by the $1974^{102}$ and 1976 Acts $^{103}$ in three ways. Section 16 provides that immunities do not apply to picketing unless the picketing is conducted at the picket's own place of work. Section 17 provides that immunities do not apply to secondary industrial actions unless such action is undertaken by employees of firms that purchase from or supply to the employer in dispute. The principal purpose of such secondary action must be to interfere with those buy/sell relationships, and the action must have a reasonable likelihood of achieving such a purpose. Finally, section 18 provides that immunities do not apply where a person induces an employee of one employer to break a

9s See Johnson, supra note 95, at 23 (citing Layard, Metcalf \& Nickell, The Effect of Collective Bargaining on Wages, paper presented to International Economic Association Conference on Personal Income Distribution, Noordwijk-aan-Zee, Netherlands (1977)).

${ }^{100}$ See supra text accompanying notes 30-31.

101 Employment Act, 1980, ch. 42.

103 See supra note 32 and accompanying text.

${ }^{103}$ See supra note 33 and accompanying tert. 
contract in order to compel employees of another employer to join a particular union. While the 1980 Act reduced the scope of union activity that is immune from tort liability, it did not weaken tradeunion immunities where they are applied to "trade disputes," narrowly defined.

The Employment Act of 1982 (the 1982 Act) ${ }^{104}$ dealt with union immunities directly. Section 15 removes the tort immunity granted to trade unions and employers' associations by the 1974 Act. ${ }^{105}$ Nonetheless, maximum damages limits are established by reference to union size, presumably to limit the likelihood of union bankruptcies, and unions' political funds and provident-benefit funds are protected from judgments. Section 18 significantly narrows the scope of "trade disputes" to issues arising wholly or mainly between workers and their employers and also restricts immunity to disputes arising within the United Kingdom. This tends to eliminate immunities for actions of a purely political nature.

The current Thatcher Government has also achieved legislation that requires pre-strike ballots and leadership elections at regular intervals. ${ }^{106}$ The potential impact of such legislation in narrowing union leaders' discretionary power is significant; the Thatcher legislation has begun to create a new climate in British labor relations. In one recently prominent union action, the $\mathrm{Na}$ tional Graphical Association (the NGA), a printers' union, called a strike against a newspaper publisher in an attempt to secure certain craft jobs against the advent of computer printing technology that made NGA members' skills obsolete. The publisher, apparently encouraged by the changing legal climate, sued successfully to enjoin the picketing. A series of fines was levied against the NGA, and when the union took the further step of picketing the whole of Fleet Street, it was exposed to the possibility of a very substantial adverse judgment. The NGA sought to strengthen its position by asking the Trades Union Council (the TUC) to approve a general strike. Although there was initially support for such action at the TUC, the potential exposure of its assets to sequestration by the courts, now a possibility under the 1980 and 1982 Acts, provided the incentive for the TUC to disapprove a general strike

104 Employment Act, 1982, ch. 46.

${ }_{105}$ Trade Union and Labour Relations Act, 1974, ch. 52, § 14; see supra note 32 and accompanying text.

${ }^{108}$ Trade Union Act, 1984, ch. 49 (available Oct. 31, 1984, on LEXIS, Enggen library, Stat file); see Vote fairly; vote not too often, Economisr, Sept. 29, 1984, at 56 (discussing the Act). 
and, ultimately, for the NGA to cease its own action against the publisher. ${ }^{107}$

These events are symptomatic of a general change of attitude among employers in Britain. After an initial period of hesitation lasting many months, employers seem to have decided that the new labor laws are to be used. ${ }^{108}$ The reaction is quite different from that of the early 1970's, when the 1971 approach of totally overhauling the labor laws was viewed as a temporary, politically charged phenomenon that would not survive a general election, and very few litigants could be found. In the absence of the 1980 and 1982 Acts, it would have been impossible for employers realistically to consider countering union coercion through the courts. As matters now stand, union resistance to industrial cost-cutting and efficiency-enhancing measures, including the use of new technology, undoubtedly is being reconsidered by the leadership. Union leaders evidently now feel that they must restrict political rentseeking unless they are prepared to expose union funds to damage suits or sequestration. The effects of the Thatcher reforms suggest that the steady increase in union power during this century is not irresistible and that step-by-step reform is possible.

\section{Conclusion}

There is far to go. Remaining legal immunities still allow union leaders to coerce their own members as well as British society as a whole. The existence of any immunities in the union sector transgresses the principle that all are equal before the law, and the closed shop infringes the freedom of workers and employers alike. Special privileges for unions perpetuate general market uncertainty and impede the creation of social wealth. If reform is to be fully effected, government will have to act to eliminate all immunities and to establish a rational system of employee rights, a system that would have at its center the fundamental right to work. It seems to me that these conclusions are in accord with basic liberal

${ }^{107}$ Much of this litigation is unreported. For a brief summary of the history of the case, see Messenger Newspapers Group Ltd. v. National Graphical Ass'n (C.A. June 15, 1984) (available Oct. 31, 1984, on LEXIS, Enggen library, Cases file).

${ }^{108}$ This is apparently not yet true of public-sector industries, which illustrates the extra leverage trade unions can achieve when key industries have been nationalized. During the ongoing British coal strike of 1984, the National Coal Board, British Rail, and British Steel have all refrained from using their legal weapons under the 1980 and 1982 Acts. On the other hand, dissident miners' groups, critical of the path mapped out by the leadership of the miners' union, have initiated legal action against their leaders in an effort to limit the exercise of discretion. See Towards a general strike?, Economist, July 14, 1984, at 12. 
principles. The world's oldest liberal democracy ought to be able to institute the reforms to which these principles point. 